doi: $10.7250 /$ iscconstrs. 2014.26

\title{
EXPERIENCE IN APPLICATION OF ANTIEROSION GEO-COMPOSITIONAL SYSTEMS FOR SUSTAINABLE DEVELOPMENT OF RECREATIONAL AND SPORTS FACILITIES
}

\author{
Elena Shcherbina1, Marina Afonina \\ ${ }^{1}$ Professor, doctor of technical Sciences, ${ }^{2}$ Associate Professor, candidate of technical Sciences, \\ ${ }^{1,2}$ Institute of Construction and Architecture of National Research University Moscow State University of Civil \\ Engineering (MGSU),Russia, 129337, Moscow, Yaroslavskoe Shosse, 26. \\ E-mail:'1ev.scherbina@yandex.ru; ${ }^{2}$ marinamgsu@yandex.ru;
}

\begin{abstract}
In this article basic results of theoretical and experimental research and monitoring data are given, which make it possible to demonstrate the need of woodland conservancy construction on recreational and sports facilities. The undertaken study demonstrated the effectiveness of the usage of geo-compositional systems, allowing to achieve topsoil stability on the surface of a slope, to establish favorable conditions for development of plant root system and to slow down overland flow. The usage of such systems is directed to achieve sustainable development of recreational and sports complexes as natural-industrial systems. The photographs of the objects are presented.
\end{abstract}

Keywords: recreational and sports complexes and objects, natural-engineering systems, geo-compositional systems, erosion processes, hills, engineering protection structure, phytoconstruction.

\section{Introduction}

Growing urbanization progress calls for new dynamic development of recreational territories for satisfying social demand for rest, sport, tourism and entertainment. Architecture and construction industry always responds quickly to the current social needs [1], development of recreational territories of Moscow Agglomeration demonstrates it today.

Such winter sports as downhill skiing and snowboard become more and more popular. Downhill skiing is a multi-purpose rest type and includes recreational, sport, amateur, health-related and ecotourism. On the territory of Moscow Province there are the entire areas, which naturally have all facilities for recreational specialization development, e.g., the Dmitrovskiy Region [2]. Forest resources, together with terrain variety and favorable natural and climatic conditions make it possible to create a highly effective resort-recreational system in the Dmitrovskiy Region, including major objects of mountain skiing and other complexes. All in all, there are more than 20 mountain skiing complexes on the territory of Moscow Agglomeration.

Discussion. In the process of area search for recreational and sports complexes, terrain, availability of open space and transport accessibility are of great importance [3, 4]. Taking into account high urbanization of Moscow Agglomeration, natural and disrupted by anthropogenic activities areas are used for siting these objects, e.g., the shooting complex «Lis'ya nora», located on the territory of a depleted pit (fig.4c). Each recreational and sports complex has a set of natural and engineering elements, soil structures, buildings, engineering and transport systems. The level of consumer appeal depends on the complex development and the variety of services provided $[5,6]$.

Additional dirt fills and dugouts, dams for ponds are set up in territories of mountain skiing complexes, which make it possible to develop water sports and their usage during summer time, for example the mountain skiing complex «Sorochany». This way, such recreational objects in a substantial way modify natural or disrupted by anthropogenic activities areas, turning into powerful industrial factors, which lead to the development of secondary landscapes where not only degradation, but also destruction of soil and vegetation covering are registered. The process of natural revegetation runs slowly on the surface of the artificial terrain, which is defined by natural climatic conditions.

The results of monitoring showed that development of erosion-slope processes is registered on the surface of hills and slopes which can lead to gully development and landslides (Fig. 1a,b; Fig. 4a), damage areas are proportional to soil structure areas. Therefore, protection of the hills against development of erosion-slope processes is one of the essential conditions of sustainable development of territories, an important task of land development focused on ecological system [3,7].

The research [8] shows that $58 \%$ of hills are fixed by grass sowing, 27\% demand topsoil salvage and grass sowing, $15 \%$ - repair of the stabilized constructions.

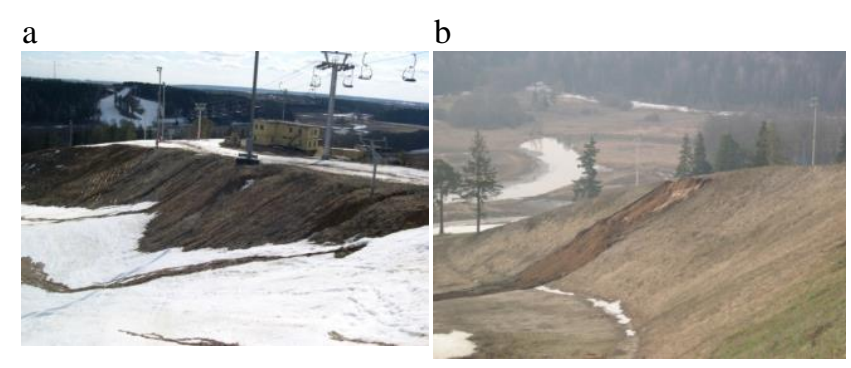

Fig. 1. Monitoring data of RSC «Sorochany»:

$\mathrm{a}-$ one of the hills before woodland conservancy work (03.2006), $\mathrm{b}$ - unexpected landslide (04.2008).

The basic functional tasks were singled out to guarantee effective engineering of woodland conservancy. They include topsoil stabilization on the surface of the slope, establishment of favorable conditions for development of plant root system, and overland flow slowdown. At the moment, different facilities are used to 
prevent the development of erosion processes, but as experience shows the most reliable and nature-friendly is the establishment of sustainable vegetable layer and surface planting, which drives flowrate to zero $[9,10,11$, $12,13]$. There are some problems in realization of this method - short vegetation period and absence of rich soil layer on the surface of the hills. Hill soil is often dead because of shortage of organic components in the soil constitution. For planting such hills it is necessary not only to apply a layer of fertile topsoil with hayseed, but also to ensure its sustainability.

As a result of the multicentre studies conducted at MSUCE $[14,15,16]$, it was established that the usage of geo-compositional systems serves as an effective solution in controlling erosion-slope processes. Geocompositional systems represent a combination of construction and biotic units (tab.1), the compound of which depends on the goals and operation conditions.

Table 1. Geocompositional system scheme

\begin{tabular}{|c|c|c|}
\hline \multicolumn{3}{|c|}{ Geocompositional system } \\
\hline $\begin{array}{c}\text { Ground } \\
\text { materials }\end{array}$ & $\begin{array}{c}\text { Geosynthetic } \\
\text { material }\end{array}$ & $\begin{array}{c}\text { Biotoc materials } \\
\text { and others }\end{array}$ \\
\hline Clays & Geonets & Soil \\
Sands & Geofabrics & Seed \\
Break Stone & Geomembranes & Bitumen \\
& Geomaterials & Rubber crumb \\
& Geotextiles & \\
\hline
\end{tabular}

Construction units form a system matrix, which serves to achieve sustainable soil, seeds and plants fixing on the surface of hills or slopes, and establishment of favorable conditions for the development of biocommunity. Matrix can be made of different building materials, and a filler compound including soil, fertilizer, seeds, binder and others. Specific structural solution, standard operating procedures and paving depend on hill ratio, topsoil components, natural climatic conditions, and are defined according to the forecast analysis of scouring rate and sustainability of the system. Engineering structure along with biological defense technology has to provide homeostasis of the formed ecosystem during the whole service life of the object, as in the phytoconstruction concept [6, 17], which is a unit of live plants with artificial or natural ground, where vegetation becomes a construction component.

\section{Monitoring}

Various alternatives of woodland conservancy were tested on the territory of recreational and sports complex (RSC) «Sorochany» built in 2001, which is situated at a distance of 40 kilometers along Dmitrovskoe Road from Moscow in the floodplain of the river Yahroma. This complex is a part of agglomerative zone of the second order, formed along Savelovskoe direction of Moscow Railway, Dmitrovskoe Road and Moscow Canal, its square is about 324 ha.

Ski slopes are built on the tell. Fill-up grounds are largely sand, rarer sabulous, heterogeneous, with numerous particles of brickbat and concrete, gravel, material debris, with layers of loam, slightly wet, of different layered structure. The bulk volume of fill-up grounds was about 2 mln. $\mathrm{m}^{3}$.

Natural terrain marks of the territory of the health resort «Sorochany» vary over the range of 145-205 m. The territory located at the top of earth fill $229.3 \mathrm{~m}$ has the maximum mark. Angle of the hill slopes average out: about $90 \%$ of the slope surface has the slope angle 250-450. Gradient grade of the other territory varies from 450 up to 600 .

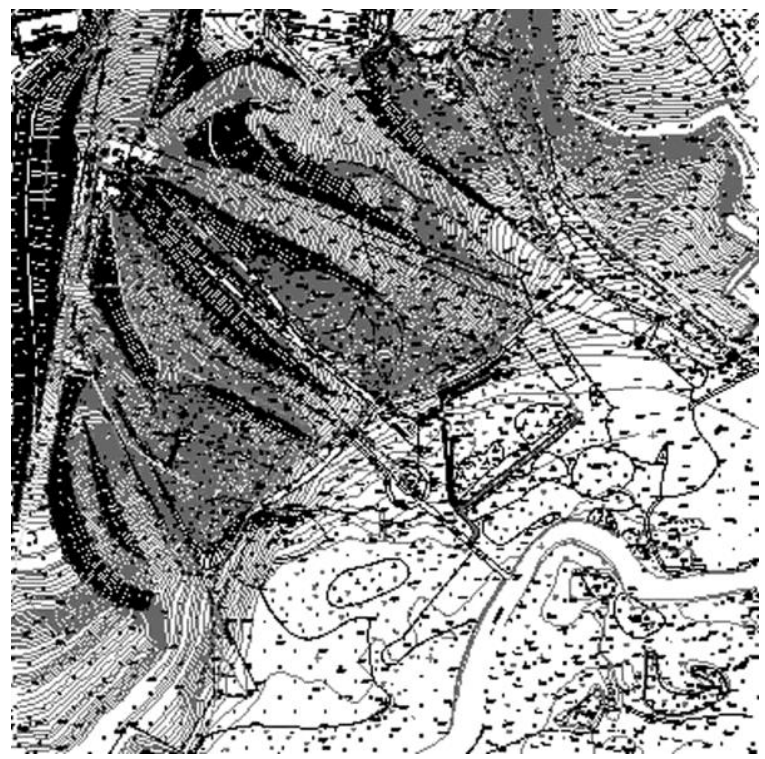

Fig. 2. Area topographic map.

The perimeter of the hill along its bottom is equal to $3422.6 \mathrm{~m}$. and has four ski slope directions, which are directed to the north, the north-east, the east and the south with the slope ratio 1:5.5 - 1:6.3. Surface area of the hill earth fill, stabilized by different ways, is $81,771 \mathrm{~m}^{2}$ (tab. 2).

Monitoring results showed that the exploitation of the ski trail down-runs has a negative impact on the state of the soil and vegetation. Development of stable sod cover and vegetation on the south side of the hill is accentuated by more marked snowmelt. On the west, south and north hills there is snow-blow from the surface (in accordance with the wind chart). $[6,18]$

Table 2. Types of antierosion stabilization used in RSC «Sorochany». [7]

\begin{tabular}{|c|l|c|c|}
\hline N/N & \multicolumn{1}{|c|}{$\begin{array}{c}\text { Types of } \\
\text { construction }\end{array}$} & $\begin{array}{c}\text { Commercial } \\
\text { operation } \\
\text { year }\end{array}$ & $\begin{array}{c}\text { Stabilizatio } \\
\text { n square } \\
\text { thous. } \mathrm{m}^{2}\end{array}$ \\
\hline 1 & Wooden constructions & 2001 & 18.8 \\
2 & Biomaterials & 2002 & 6.03 \\
3 & Geosynthetic material & 2004 & 10.553 \\
4 & construction & 2004 & 4.674 \\
5 & Mesh structures & 2005 & 16.57 \\
\hline
\end{tabular}


Geological structure of the tumulus was measured by 5 engineering-geological sections, located in the areas where works aimed at the protection of artificial fill-up hill against the development of erosion processes were being conducted.

Disposal run was used for rain water and melt water disposal from the slope surface, it was made of Renault pads with dimensions of $3 \times 2 \times 0.23 \mathrm{~m}$, set along geotextile. Parameters of the run were rated for passing of $20 \mathrm{l} / \mathrm{sec}$ and the run has the bottom width $-0.6 \mathrm{~m}$, the depth-0.5 m, the lenght $-348 \mathrm{~m}$.

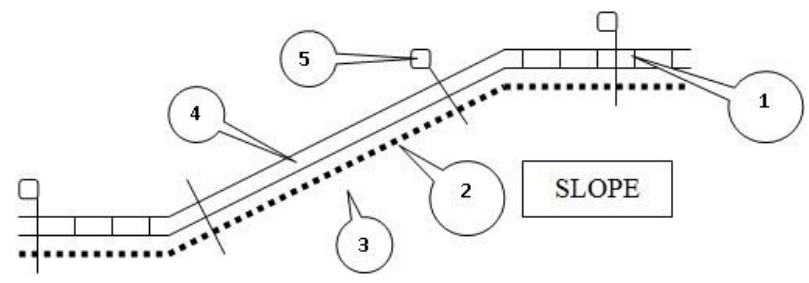

Fig. 3. Structural scheme of the slope protection by 3-4 geocells PRUDON -494: 1- geocells PRUDON -494, 2 - geotextile, 3 - consolidated soil of the slope surface, 4 - soil and subsoil, 5 - iron-cramp anchors.

Figure 3 demonstrates the construction of the slope protection against the development of erosion processes with the help of geocells PRUDON with topsoil filling operations with regrassing. Such slope reinforcement constructions were created in August-September 2005 in accordance with the FSUE project «Souzdornii».

The retaining wall made of geonets AR-3 was set at the top of the section with filling the cells with native soil. The textile layer was set under each layer of geonets. Slope surfaces (top and bottom levels) were reinforced by the geocell AR-2 with turf-sand mixture and regressing was made. Geocells top edges through slope crest were set in cutting $0.4 \times 0.4 \mathrm{~m}$ and were concreted.

Geotextile layer was set under geocells on the slopes. Fixing of geocells against each other and to the slopes was made with the help of steel anchors in length of $0.8-1.2 \mathrm{~m}$. Slope length through generant is equal to $292 \mathrm{~m}$.

The second object of monitoring is RSC «Lis'ya nora», it is the largest sports-shooting complex in Russia and Europe. This complex is situated in the former borrow of sand and gravel excavation «Gurban», which was exploited during 1982 and 2000, original square was 80 ha, edge height up to $31 \mathrm{~m}$, edge location angles from 28.80 up to 32.50 [9]. There are more than 20 organized sites for sporting, Olympic traps and 10, 25 and 50 meter ranges on its territory. Top level competitions are held in 300 meters shooting galleries. The complex includes a hotel complex, great sand beaches, natural lake, boating and cycling, fishing, golf, badminton and tennis courts, and restaurants. All the sportsmen and guests move only by electric vehicles on the territory of the complex. Here you can even see deers and roedeers. a
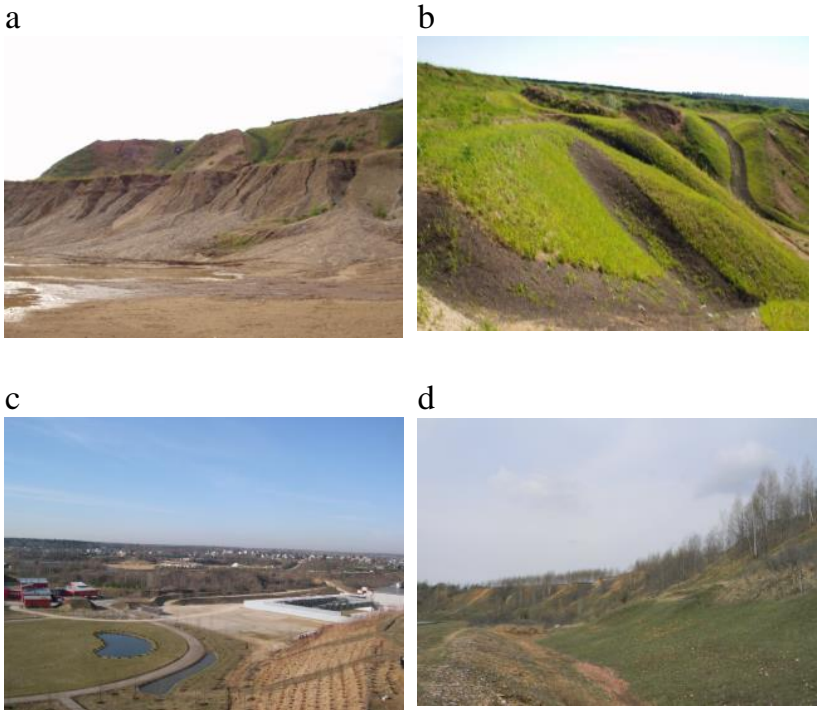

Fig. 4. Sports-shooting complex «Lis'ya nora» MR: .a - hills at the start of protecting works in 2003; b - fragment of catchwater drain, stabilized using geo-compositional system (2005); c - implantation of the bushes aslope (2007); $d$ - the slopes in spring 2013 (authors' photography).

The complexity of this object was that it was initially established on the territory of a depleted pit, its hills were liable to the development of erosion and slope processes (Fig. 4a). The results of calculation showed that hills were in steady-state conditions, and emergent landslides were the result of water erosion $[9,20,21]$. A set of measures was implemented to ensure woodland conservancy, which included: organization of overland flow with water removal in protected channels of the formed gulleys, strengthening of the hills by sowing grass and bushes (Fig. 4c,d). Proofing of slope drains and water streams was done using geo-compositional systems. The system matrix is composed of geosynthetical material, 3rd structural antierosion geomaterial with the fiber thickness of $0.5 \mathrm{~mm}$, the porosity of 0.95 , thickness of $10 \mathrm{~mm}$ and $18 \mathrm{~mm}$, the tensile strength. $8 \mathrm{kN} / \mathrm{m}$ and $1.9 \mathrm{kN} / \mathrm{m}$, accordingly 1 [9]. The filler is soil ground with hayseed, fixed with the use of bitumen-based binder in the areas of water stream. As a result, development of erosion processes was stopped in a year upon the performance of work (Fig. 4b). The obtained results also made it possible to validate experimentally an abstract model, allowing forecasting erosive speed for hills formed by granular soil.

\section{Conclusions}

Guarantee of reliable and effective protection of the hills against the development of erosion and slope processes can be put into practice on the basis of engineering and technical measures, including:

- engineering geology;

- overall stability calculation;

- critical erosive speed definition;

- overland flow organization;

- application of geo-compositional system for woodland conservancy projection; 
- plant complex selection taking into account particular conditions.

Geotechnical monitoring serves as a necessary resource to achieve sustainable development of recreational and sports complexes; it also can include elements of ecological monitoring that will make it possible to ensure ecological safety of the territory.

\section{References}

Strauskas, V.P., 1977. Gradostroitel'naja organizacija rajonov i centrov otdyha. L. Strojizdat, Leningr. Otd-nie. $164 \mathrm{~s}$

Afonina, M. I.; Burova, M. M., 2012. Analiz razvitija rekreacionnyh kompleksov dlja zimnih vidov sporta moskovskoj aglomeracii.Sbornik nauchnyh trudov SWorld. Materialy mezhdunarodnoj nauchno-prakticheskoj konferencii «Sovremennye problemy i puti ih reshenija $\mathrm{V}$ nauke, transporte, proizvodstve i obrazovanii'2012». Vypusk 4. Tom 50. - Odessa:KUPRIENKO, 2012. - CIT: 412-1050. - S.18-23

Afonina, M.I., 2013. Ob'ektivnye predposylki dlja stroitel'stva vremennyh zimnih innovacionnyh sportivnyh sooruzhenij (na primere Moskvy). Materialy 3-j mezhdunarodnoj nauchno-prakticheskoj konferencii "Jenergointegracija 2013" maj 2013 g. Kiev Ukraina. Nauchno-tehnicheskij sbornik "Energoefektivnict' v budivnictvi ta aphitekturi", No. 4.

Afonina, M.I., 2012. Jekstremal'nye zimnie sportivnye trassy v uslovijah bol'shih gorodov. Jelektronnoe nauchnoe izdanie "Naukovedenie", 4(13), 2012. 108TVN412, Available at: http://www.aspirantur.ru/zhurnal-vak-naukovedenieelektronnyj-zhurnal.html

Telichenko, V.I.; Rojtman, V.M.; Slesarev, M.Ju.; Shherbina E.V., 2011. Osnovy kompleksnoj bezopasnosti stroitel'stva: Monografija / Pod redakciej V.I. Telichenko i V. M. Rojtmana. - M.: Izd. ASV. 168 s.

Afonina, M. I., 2008. Sportivnye i rekreacionnye jekologicheski ustojchivye prirodno-tehnicheskie sistemy. (na primere gornolyzhnogo kurorta Sorochany). Zh. Jekologija urbanizirovannyh territorij, No.1, c. 81-86.

Shherbina, E.V.; Afonina, M.I.; Otchercov, M.V.; Shatohin V.N. Protivojerozionnaja zashhita iskusstvennyh gruntovyh sooruzhenij. (Opyt jekspluatacii gornolyzhnogo kurorta «Sorochany») Trudy Jubilejnoj konferencii, posvjashhennoj 50-tiletiju ROMGGiF Moskva.

Roadside erosion causes and factors: Minnesota survey analysis. Sullivan R., Foot L.E "Ttansp.Res.Rec.". 1983 N 948, 47-54.

Alekseev, A.A. Geojekologicheskaja jeffektivnost' primenenija geokompozicionnyh jekranov pri vosstanovlenii landshaftov, narushennyh gornodobyvajushhej dejatel'nost'ju. Avt. diss. na soisk .uch.stepeni kand. teh.nauk. MGSU Moskva.

Shherbina, E. V., 2004. Geosinteticheskie materialy v stroitel'stve. M. : Izd-vo ASV, 2004. - $111 \mathrm{~s}$

Slepnev, P.A., Shherbina E.V. Rol' dlitel'noj prochnosti geosinteticheskogo materiala $\mathrm{v}$ raschetah $\mathrm{i}$ proektirovanii protivojerozionnoj zashhity sklonov / Zh. Academia. Arhitektura i stroitel'stvo. M. 2010 g., s. $578-581$.

Slepnev P. A., 2009. Obosnovanie jeffektivnoj zashhity ot jerozii jelementov vodnyh rekreacionnyh ob'ektov goroda [Tekst]. Aktual'nye zadachi i perspektivy razvitija gorodskogo stroitel'stva i hozjajstva: sb. nauch. tr. fak. Gorodskogo str-va i hoz-va MGSU, Vyp. 2. / Moskovskij gosudarstvennyj stroitel'nyj universitet, In-t str-va i inzhenernoj infrastruktury. - M.: Prima-press Jekspo, 2009. S. 97-100.

Slepnev, P.A., 2006. Ocenka opasnosti jerozionno-ruslovyh processov, razvivajushhihsja na vodoemah i vodotokov urbanizirovannyh territorij [Tekst]. Jekologija urbanizirovannyh territorij: sb. materialov Mezhdunarodnoj nauchno-tehnicheskoj konferencii. - M.: Prima-press M, S. 235-237.

Volodina, L.A.; Slepnev, P.A., 2011. Sovershenstvovanie tehnologii monitoringa gorodskih territorij, podverzhennyh opasnym jekzogennym geologicheskim processam [Tekst]. L. A. Volodina, P. A. Slepnev. Integracija, partnerstvo i innovacii $\mathrm{v}$ stroitel'noj nauke i obrazovanii: sbornik trudov: v 2 t. / Moskovskij gosudarstvennyj stroitel'nyj universitet (NIU); [pred.konf. V. I. Telichenko; zam. pred.: O. O. Egorychev [i dr.]. - M: MGSU, 2011 g., T. 1. - S. 397-399.

Afonina, M.I., 2008. Problemy biologicheskoj zashhity otkosov zemljanogo polotna ob'ektov transportnogo stroitel'stva [Text]. Zh. Jekologija urbanizirovannyh territorij N1. c. 81-86.

Afonina, M.I., 2012. Vybor optimal'nogo reshenija protivojerozionnoj zashhity dorozhnyh i rekreacionnyh ob'ektov s ispol'zovaniem kvalimetrii.Zh. Dorogi Rossii XXI veka N4.

Afonina, M.I.; Balaban, V.V., 2013. Moskovskie innovacionnye proekty dlja zimnih sorevnovanij Zh. Jekologija urbanizirovannyh territorij No. 1. pp. 75-79.

Afonina, M.I., 2000. Issledovanija fitokonstruktivnyh modulej dlja sanacii gorodskoj sredy i razrabotka tehnologii ih sozdanija i vnedrenija. Avtoreferat.dis. na soiskanie uchenoj st. k.t.n. MGSU M.

Afonina, M.I.; Korobko, A.M., 2011. Statisticheskij analiz vlijanija klimaticheskih faktorov na razvitie sportivnorekreacionnogo kompleksa «Sorochany» MO [Text]. Periodicheskoe nauchnoe izdanie, Nauchno tehnicheskijtehnicheskij zhurnal «Vestnik «MGSU», No.1 , t.II, pp. 24-29.

Afonina, M. I.; Burova, M. M., 2013. Opredelenie «Kojefficienta privlekatel'nosti» RSK «Sorochany» metodom kvalimetricheskoj ocenki. Materialy mezhdunarodnoj konferencii «Nauchnye chtenija, posvjashhennye 100-letiju Ju.B.Monfreda MGSU Moskva. 299 c.

Slepnev, M.A.; Shherbina, E.V., 2011. Primenenie GIStehnologij $\mathrm{V}$ reshenii razvitija $\mathrm{i}$ reabilitacii prirodnyh territorij [Tekst] / M. A. Slepnev, E. V. Shherbina. Integracija, partnerstvo i innovacii $\mathrm{v}$ stroitel'noj nauke $\mathrm{i}$ obrazovanii: sbornik trudov: $\mathrm{v} 2$ t. Moskovskij gosudarstvennyj stroitel'nyj universitet (NIU); [pred.konf. V. I. Telichenko; zam. pred.: O. O. Egorychev [i dr.]. - M. : MGSU., T. 1. - pp. 461-465.

Aktual'nye zadachi i perspektivy razvitija gorodskogo stroitel'stva i hozjajstva [Tekst]: sb. nauch. tr. fak. Gorodskogostr-va i hoz-va MGSU / Moskovskij gosudarstvennyj stroitel'nyj universitet, In-t str-va i inzhenernoj infrastruktury. - M.: Prima-press Jekspo, 2009 Aktual'nye zadachi i perspektivy razvitija gorodskogo stroitel'stva i hozjajstva : sb. nauch. tr. fak. Gorodskogo strva i hoz-va MGSU. Vyp. 2 / Moskovskij gosudarstvennyj stroitel'nyj universitet ; pod obshh.red. V.F.Kas'janova, E.V.Shherbiny. - M. : Prima-press Jekspo, 2009. - 220 s. 